\title{
Anxiolytic- and antidepressant-like effects of the ethanolic extract from Citrus limon plant widely used in Northeastern Brazil
}

\author{
Francisco Rodrigo de Asevedo Mendes de Oliveira ${ }^{1}$, Gilberto Santos Cerqueira ${ }^{2}$, Rizângela \\ Lyne Mendes de Freitas ${ }^{2}$, Joaquim Soares Costa Júnior ${ }^{3}$, Chistiane Mendes Feitosa $^{4}$ and \\ Rivelilson Mendes de Freitas ${ }^{1 *}$ \\ ${ }^{1}$ Post-Graduation Program in Pharmaceutics Science, Federal University of Piaui, Teresina, Piaui, Brazil. \\ ${ }^{2}$ Federal University of Ceará, Fortaleza, Ceará, Brazil. \\ ${ }^{3}$ Department of Chemistry, Federal Institute of Piaui, Teresina, Piaui, Brazil. \\ ${ }^{4}$ Department of Chemistry, Federal University of Piaui, Teresina, Piauí, Brazil.
}

Accepted 22 July, 2013

\begin{abstract}
Anxiolytic and antidepressant effects and acute toxicity of ethanolic extract (EE) from Citrus limon were studied in mice. Anxiolytic activity was evaluated using open field and elevated plus-maze tests. The antidepressant effect of the extract was studied by forced swimming test in mice. Phytochemical screening of the ethanolic extracts indicated the presence of cumarin and triterpenoids/steriods. In the open field test, the oral route administration EE alone showed significant sedative and antidepressant activities in mice $(p<0.05)$. EE did not alter motor coordination. The EE, at three doses tested, showed antidepressant effect and produced decrease in immobility time. It is concluded that the EE of the aerial parts of $\boldsymbol{C}$. limon have a sedative effect, which may be mediated by benzodiazepine-type receptors, and also an antidepressant effect where noradrenergic and serotoninergic mechanisms will probably play a role.
\end{abstract}

Key words: Antidepressant, anxiolytic, Citrus limon, ethanolic extract, sedative.

\section{INTRODUCTION}

Depression and anxiety are the most frequent mental disorders. More than $20 \%$ of the adult population suffers from these conditions (Buller and Legrand, 2001). The World Health Organization (WHO, 1999) predicts that depression will become the second leading cause of premature death or disability worldwide by the year 2020 . The genus Citrus possesses about 70 species of subshrubs and shrubs that can be grown or naturally found in Germany, Spain, Mexico, Venezuela, Cuba, Jamaica, Ecuador and Northern and Northeastern Brazil
(Lorenzi and Matos, 2002). The Citrus are also known to exhibit various biological activities such as antioxidant (Campêlo et al., 2011a, b; Misharina and Samusenko, 2008), antimicrobial (Choi et al., 2000), anti-inflammatory (Benavente-Garcia and Castillo, 2008), insecticide (Karr and Coats, 1988) and inhibition of acetylcholinesterase (AChE) enzyme (Conforti et al., 2007).

Citrus fruits are known to contain natural antioxidants in its oil, pulp, seed and bark. According to Pereira (Pereira, 1996), the methanol extracts of seeds of lemons has 
antioxidant activity. Studies show that ethyl acetate and methanol extract from Citrus limon leaves have anticholinesterasic activity as seen with the standard galanthamine, which is considered to be the most effective compound in the treatment of Alzheimer's disease (Feitosa et al., 2011). Citrus peel and seed represent natural sources of phenolic compounds, including phenolic acids and flavonoids (Bocco et al., 1998).

C. limon Burms (Rutaceae), popularly known as "limão", has as the major constituents essential oils limonene $(52.77 \%)$, geranyl acetate $(9.92 \%)$ and translimonene-oxide (7.13\%) (Campêlo et al., 2011b). Other studies also showed that $C$. limon essential oil presents larvicidal activity against Aedes aegypti L. (Furtado et al., 2005). Studies showed the insecticidal properties of $d$ limonene major constituents of $C$. limon essential (Karr and Coats, 1988).

Previously, we showed in our laboratory that essential oil of $C$. limon leaves reduces the lipid peroxidation and nitrite content as well as increase the glutathione reduced (GSH) levels and enzymatic antioxidant activities (superoxide dismutase, catalase and glutathione peroxidase) in mice hippocampus. These findings strongly support the hypothesis that oxidative stress in hippocampus might occur during neurodegenerative diseases, proving that hippocampal damage induced by the oxidative process plays a crucial role in brain disorders, which implies that a neuroprotective effect could be achieved using $C$. limon essential oil as antioxidant treatment (Campêlo et al., 2011b). Other studies suggest a possible depressant action of $C$. limon essential oil on central nervous system (CNS) and anticonvulsant activity in seizures model induced by pentylenetetrazole (Campêlo et al., 2011a).

The purpose of the present work was to analyze the effects produced by the acute administration of the ethanolic extract from $C$. limon using the open field, elevated-plus-maze, rota rod, and forced swimming tests in order to evaluate the anxiolytic and antidepressant activities of this medicinal plant, attempting to clarify their mechanism of action.

\section{MATERIALS AND METHODS}

\section{Plant}

C. limon was identified and collected by Chistiane Mendes Feitosa in February, 2010, at the city of Picos, state of Piaui, Brazil. The voucher specimen (number 26.453) was deposited at the Graziella Barroso Herbarium of the Federal University of Piauí. Ethanolic extract of $C$. limon leaves was prepared in Laboratory of Chemistry of Natural Products at Federal University of Piauí, Teresina, Piauí.

\section{Ethanolic extract preparation}

The leaves collected from the C. limon were dried at $55^{\circ} \mathrm{C}$ under shade and powdered mechanically. $10 \mathrm{~g}$ of crushed leaves was extracted with water $(70 \%$, w/w), followed by ethanol $(\mathrm{EtOH})(30 \%$, $w / w)$. The extract was concentrated in a vacuum evaporator. The concentrated extract was finally freeze-dried to get the yield of $10 \%$ of ethanolic extract. The dried extract was kept at $4^{\circ} \mathrm{C}$ in a refrigerator in the air tight bottles until use.

\section{Drugs and reagents}

The ethanolic extract (EE) was emulsified with $0.5 \%$ Cremophor (Sigma, USA) in distilled water. Diazepam (DZP) was purchased from the (União Química, Brazil) and used as standard. Reserpine sulphate (RESERP) was purchased from the Sigma Chem. Co. (St. Louis, MO, USA). Imipramine (IMI) and Paroxetine (PAROX) were purchased from the Novartis Biociências S.A. (São Paulo, Brazil) and Glaxo Smith Kline Brasil Ltda (Rio de Janeiro, Brazil), respectively. All other drugs were of analytical grade.

\section{Animals and behavioral tests}

Male Swiss mice (25 to $30 \mathrm{~g}$ ) were used. All animals were maintained at a controlled temperature $\left(25 \pm 1^{\circ} \mathrm{C}\right)$ and a 12-h dark/light cycle. Animals had free access to water and food. All behavioral tests were conducted in quiet rooms at the same controlled conditions referred above. Different groups of mice were used for each behavioral task. For each experiment, mice were randomized into five groups (7 mice per group): one control group treated with the vehicle, three groups treated with EE at 50, 100 and $150 \mathrm{mg} / \mathrm{kg}$, and a fifth drug reference group treated with imipramine ( 25 or $50 \mathrm{mg} / \mathrm{kg}$; forced swimming test), paroxetine (10 or $20 \mathrm{mg} / \mathrm{kg}$; forced swimming test), reserpine $(0.25 \mathrm{mg} / \mathrm{kg}$; forced swimming test) or DZP ( 0.75 or $2 \mathrm{mg} / \mathrm{kg}$; open field, rota rod). Treatment with EE or vehicle was given orally (p.o.) via gastric gavage $(10 \mathrm{ml} / \mathrm{kg})$ for 30 days. All experiments were performed according to the Guide for the Care and Use of Laboratory Animals, from the US Department of Health and Human Services, Washington DC, 1985. Experimental protocols and procedures were approved by the Ethics Committee on Animal Experiments at the Federal University of Piauí (CEEA/UFPI \# 013/2011).

\section{Experimental protocol and behavioral screening}

After the treatment, each animal was submitted to a series of tests in the manner described below. Firstly, the animal was observed in a closed room at constant temperature $\left(25 \pm 1^{\circ} \mathrm{C}\right)$. Then, the animal was placed inside a plus maze and observed for $5 \mathrm{~min}$. Immediately after the plus maze test, it was placed in the open field area for more 5 min. After that, the animal was removed to the rota rod where it was evaluated for 1 min. Finally, its temperature was taken with a digital thermometer. All the tests were performed between 08:00 a.m. and 10:00 p.m. The animals had free access to food and water during testing. The behavioral screening of the mice was performed according to the parameters described by Almeida et al. (1999). Animals were observed at $24 \mathrm{~h}$ after the EE C. limon administration (50, 100 and $150 \mathrm{mg} / \mathrm{kg}$, p.o.). During $24 \mathrm{~h}$ we observed the occurrence of the following general signs of toxicity: piloerection, prostration, writhing, increased evacuation, grooming, discrete groups, dyspnoea, sedation, analgesia and palpebral ptosis.

\section{Open field test}

Mice were randomly allocated to the following groups: control (0.05\% Tween 80 , dissolved in $0.9 \%$ saline, p.o.), diazepam (2.0 
$\mathrm{mg} / \mathrm{kg}$, i.p.) and ethanolic extract from C. limon (50, 100 and 150 $\mathrm{mg} / \mathrm{kg}$, i.p.), that received acute treatment acute with single dose before open field test. The open-field arena was made of acrylic (transparent walls and black floor, $30 \times 30 \times 15 \mathrm{~cm}$ ), divided into nine squares of equal areas. The open field was used to evaluate the exploratory activity of the animal (Archer, 1973). The observed parameters were the number of squares crossed (with the four paws) and number of grooming and rearing, recorded for $5 \mathrm{~min}$ testing period.

\section{Elevated plus maze test (EPM)}

Mice were randomly allocated to the following groups: control $(0.05 \%$ Tween 80 , dissolved in $0.9 \%$ saline, p.o.), diazepam $(0.75$ $\mathrm{mg} / \mathrm{kg}$, i.p.) and ethanolic extract from C. limon (50, 100 and 150 $\mathrm{mg} / \mathrm{kg}$, i.p.), that received treatment acute with single dose before of open field test. This test has been widely validated to measure anxiety in rodents (Lister, 1987). The elevated plus maze (EPM; 30 $\times 6 \times 6 \mathrm{~cm}$, each arm) made of wood and consisting of two open and two closed arms across each other, respectively is placed 60 $\mathrm{cm}$ above the ground level. After treatment, the animal was placed at the center of the plus maze with its nose in the direction of one of the closed arms, and observed for $5 \mathrm{~min}$, following the parameters: number of entries in the open and closed arms, and time of permanence in each of them. The time of permanence measures the time spent by the animal in the open and closed arms (Lister, 1987).

\section{Forced swimming test}

Mice were randomly allocated to the following groups: control $(0.05 \%$ Tween 80 , dissolved in $0.9 \%$ saline, p.o.), imipramine (25 and $50 \mathrm{mg} / \mathrm{kg}$, i.p.), paroxetine (10 and $20 \mathrm{mg} / \mathrm{kg}$, i.p.), reserpine $(0.25 \mathrm{mg} / \mathrm{kg}$, i.p.), and ethanolic extract from C. limon (50, 100 and $150 \mathrm{mg} / \mathrm{kg}$, i.p.), that received treatment acute with single dose before behavioural test. For assessing antidepressant activities, we employed the method described by Porsolt et al. (1977a, b; 1978). The development of immobility when mice were placed inside an inescapable cylinder filled with water reflects the cessation of persistent escape-directed behavior. Briefly, mice were individually placed in a circular tank $(46 \mathrm{~cm}$ tall $\times 20 \mathrm{~cm}$ in diameter) filled with tap water $\left(25 \pm 1^{\circ} \mathrm{C}\right)$ to a depth of $20 \mathrm{~cm}$ and left there for $5 \mathrm{~min}$. During this period, the behavior of the animals was recorded by an observer. Mice were considered immobile when remained floating without struggling and making only slight movements necessary to maintain the head above the water.

\section{Rota rod test}

Mice were randomly allocated to the following groups: control $(0.05 \%$ Tween 80 , dissolved in $0.9 \%$ saline, p.o.), diazepam $(0.75$ $\mathrm{mg} / \mathrm{kg}$, i.p.) and ethanolic extract from C. limon (50, 100 and 150 $\mathrm{mg} / \mathrm{kg}$, i.p.), that received acute treatment with single dose before rota rod test. The mice were trained before the experiment to develop the ability to remain for $1 \mathrm{~min}$ on a $25 \mathrm{~mm}$ diameter rod rotating at $17 \mathrm{rpm}$. Two or three trials were usually enough for the animals to learn this task. For the rota rod test, for each animal, the number of falls (up to three falls) and the time of permanence on the bar for $1 \mathrm{~min}$ were recorded (Dunham and Miya, 1957).

\section{Rectal temperature}

Animals rectal temperatures were taken at the end of the tests with a digital thermometer.

\section{Statistical analysis}

Results were expressed as means \pm SEM and analyzed with analysis of variance (ANOVA) and the $t$-Student-Neuman-Keuls as post hoc test $(p<0.05)$.

\section{RESULTS}

Phytochemical screening of the ethanolic extracts indicated the presence of cumarin and triterpenoids/steroids and the absence of alkaloids, flavonoids, tannins and saponins. The determination of the chemical constituents was carried out according to the previous methodology proposed (Matos, 2009; Barbosa, 2004). Ethanolic extract from C. limon at doses of 50,100 and $150 \mathrm{mg} / \mathrm{kg}$ p.o. caused behavioral changes in animals during 30 days of treatment: decrease of spontaneous activity, palpebral ptosis, ataxia, analgesia, and sedation. Behavioral changes were more evident on the second day of treatments.

In the open field test (Table 1), EE $(50 \mathrm{mg} / \mathrm{kg}$, p.o.) decreased in $31 \%$ the number of rearings in comparison with the control. Similarly, EE $100(100 \mathrm{mg} / \mathrm{kg}$, p.o.) and EE $150(150 \mathrm{mg} / \mathrm{kg}$, p.o.) decreased the number of rearings (31 and $70 \%$, respectively) and also led to grooming reduction. In EE 50 group there was decreased number of crossings by $33 \%$ when compared to control. In the same way, EE 100 and EE 150 decreased the number of crossings, as compared to control at the doses used in the present work (51 and 61\%, respectively). Diazepam showed sedative effect at the dose used (2 $\mathrm{mg} / \mathrm{kg}$, i.p.).

Table 2 shows the effects of EE from $C$. limon in the plus maze test. Among the parameters used for evaluation of the anxiolytic activity, the control group presented the following data: number of entries in the open arms (NEOA); time of permanence in the open arms (TPOA). EE $50 \mathrm{mg} / \mathrm{kg}$ (i.p.) decreased NEOA ( $p<$ $0.05)$ and increased TPOA $(p<0.05)$. Differently, the highest dose of EE decreased NEOA, TPOA $(p<0.01)$. NEOA and TPOA were also increased by EE, $100 \mathrm{mg} / \mathrm{kg}$ i.p. when compared to control. Diazepam $(0.75 \mathrm{mg} / \mathrm{kg}$, i.p.) significantly increased all these parameters. An anxiolytic compound reduces the natural animals' aversion to the open arms and promotes the exploration thereof. On the other hand, the forced or voluntary passages of the animal into the open arms of the EPM are associated with hormonal and behavioral changes indicative of increased anxiety (Lister, 1987; Hogg, 1966).

The possible antidepressant effect of $\mathrm{EE}$ after oral administration was studied in the forced swimming test (Table 3). Under this condition, EE was used at higher doses (50, 100 and $150 \mathrm{mg} / \mathrm{kg}$, p.o.), since at these three doses the antidepressant effect is not masked by the sedative and anxiolytic effects. The results showed that EE presents a significant antidepressant effect (50, 100 
Table 1. Effects of EE from C. limon on the open field test in mice.

\begin{tabular}{lccc}
\hline Groups & Number of squares crossed & Rearing & Grooming \\
\hline Control & $91.38 \pm 10.41$ & $38.00 \pm 7.59$ & $4.75 \pm 2.18$ \\
DZP 2 & $35.20 \pm 6.76^{\mathrm{a}}$ & $18.20 \pm 5.26^{\mathrm{a}}$ & $1.60 \pm 0.89^{\mathrm{a}}$ \\
EE 50 & $63.60 \pm 19.76^{\mathrm{a}, \mathrm{b}}$ & $25.40 \pm 2.40^{\mathrm{a}, \mathrm{b}}$ & $3.60 \pm 0.89^{\mathrm{a}, \mathrm{b}}$ \\
EE 100 & $63.40 \pm 19.93^{\mathrm{a}, \mathrm{b}}$ & $18.60 \pm 5.77^{\mathrm{a}, \mathrm{c}}$ & $3.80 \pm 1.30^{\mathrm{a}, \mathrm{b}}$ \\
EE 150 & $27.40 \pm 4.83^{\mathrm{a}, \mathrm{b}, \mathrm{c}, \mathrm{d}}$ & $14.80 \pm 2.38^{\mathrm{a}, \mathrm{b}, \mathrm{c}, \mathrm{d}}$ & $4.00 \pm 1.41^{\mathrm{a}, \mathrm{b}, \mathrm{c}, \mathrm{d}}$ \\
\hline
\end{tabular}

Values are the mean \pm S.E.M. for number of squares crossed, rearing and grooming of 7 mice (per group) used in the experiments. ${ }^{a} p<0.01$ (ANOVA followed by Student-Neuman-Keuls $t$-test), significantly different from control. ${ }^{b} p<0.001$ (ANOVA followed by Student-Neuman-Keuls $t$-test), significantly different from DZP. ${ }^{c} p<0.001$ (ANOVA followed by Student-Neuman-Keuls $t$-test), significantly different from EE 50 group. ${ }^{d} p<0.001$ (ANOVA followed by Student-Neuman-Keuls $t$-test), significantly different from EE 100 group.

Table 2. Effects of EE from C. limon on the plus maze test in mice.

\begin{tabular}{lcccc}
\hline Groups & NEOA & PEOA & TPOA & PTOA \\
\hline Control & $8.71 \pm 2.63$ & $34.86 \pm 1.51$ & $116.71 \pm 3.54$ & $38.90 \pm 1.18$ \\
DZP 0.75 & $15.71 \pm 0.75$ & $62.86 \pm 3.02$ & $206.86 \pm 7.15$ & $68.95 \pm 2.38$ \\
EE 50 & $6.60 \pm 1.52^{\mathrm{a}, \mathrm{b}}$ & $26.40 \pm 6.07^{\mathrm{a}, \mathrm{b}}$ & $152.00 \pm 25.64^{\mathrm{a}, \mathrm{b}}$ & $50.67 \pm 8.55^{\mathrm{a}, \mathrm{b}}$ \\
EE 100 & $13.60 \pm 1.95^{\mathrm{a}, \mathrm{b}, \mathrm{c}}$ & $54.40 \pm 7.80^{\mathrm{a}, \mathrm{b}, \mathrm{c}}$ & $173.00 \pm 17.89^{\mathrm{a}, \mathrm{b}, \mathrm{c}}$ & $57.67 \pm 5.96^{\mathrm{a}, \mathrm{b}, \mathrm{c}}$ \\
EE 150 & $4.40 \pm 1.34^{\mathrm{a}, \mathrm{b}, \mathrm{c}, \mathrm{d}}$ & $17.60 \pm 5.37^{\mathrm{a}, \mathrm{b}, \mathrm{c}, \mathrm{d}}$ & $83.60 \pm 4.16^{\mathrm{a}, \mathrm{b}, \mathrm{c}, \mathrm{d}}$ & $27.87 \pm 1.39^{\mathrm{a}, \mathrm{b}, \mathrm{c}, \mathrm{d}}$ \\
\hline
\end{tabular}

Each values represents mean \pm S.E.M. of NEOA, number of entries in the open arms; PEOA, percentage of entries in the open arms; TPOA, time of permanence in the open arms; PTOA, percentage of time in the open arms. Values are the mean \pm S.E.M. for 7 mice (per group) used in the experiments. ${ }^{a} p<0.01$ (ANOVA followed by Student-Neuman-Keuls $t$-test), significantly different from control. ${ }^{b} \mathrm{p}<0.001$ (ANOVA followed by Student-Neuman-Keuls $t$-test), significantly different from DZP. ${ }^{c} p<0.001$ (ANOVA followed by Student-Neuman-Keuls $t$-test), significantly different from EE 50 group. ${ }^{d} p<0.001$ (ANOVA followed by Student-Neuman-Keuls $t$-test), significantly different from EE 100 group.

and $150 \mathrm{mg} / \mathrm{kg}$ ), as seen in decreasing of the time of immobility $(28,51$ and $70 \%$, respectively). The lowest dose $(25 \mathrm{mg} / \mathrm{kg})$ was devoid of any significant effect. The association of EE $150 \mathrm{mg} / \mathrm{kg}$ with imipramine (IMI) showed a decrease of 6 and $15 \%$ in the immobility time, as related to the groups treated with EE alone (150 $\mathrm{mg} / \mathrm{kg}, \mathrm{p}<0.01)$ or IMI $(\mathrm{p}<0.05)$ alone, respectively. In addition, the association of EE with paroxetine $(p<0.01)$ alter the effect observed with EE or paroxetine alone $(p<$ 0.05 ), suggesting that the serotonergic system is involved in the antidepressant effect of EE. On the contrary, the EE activity was totally blocked by the previous administration of reserpine. These data suggest that the noradrenergic and serotoninergic system participates in the EE antidepressant action.

Table 4 shows the effects of EE from $C$. limon in the rota rod test, a method used for evaluating motor coordination and presence of any muscle relaxation effect. It revealed that there was no change in the number of falls after EE administration (50, 100 and $150 \mathrm{mg} / \mathrm{kg}$, p.o.) when compared to controls (Table 4). Additionally, only $E E$ at $150 \mathrm{mg} / \mathrm{kg}, p . o$. decreased in $18 \%$ the time of permanence on the bar in relation to control. Diazepam $(0.75 \mathrm{mg} / \mathrm{kg}$, i.p.), like EE 50 and 100 , was devoid of effect. The rectal temperature of the control group has been show in Table 5. The doses of 50, 100 and 150 $\mathrm{mg} / \mathrm{kg}$, p.o. decreased the rectal temperature, in a dose independent way.

\section{DISCUSSION}

In the present work, the central effects of the ethanolic extract (EE) of leaves from C. limon were evaluated. EE was firstly analyzed on the open-field test which gives a good indication of the animal's emotional state. The results showed that EE was able to significantly decrease not only the number of crossings, indicative of a possible sedative effect, but also grooming and rearing. The action mechanism of the sedative effect of this EE has not been elucidated yet. However, the reduction in the number of rearings and crossings in the open field test confirms the central activity of this EE, since it is known that rearing is a function of the excitability level of the central nervous 
Table 3. Effects of EE from $C$. limon in mice in model of forced swimming.

\begin{tabular}{lcc}
\hline Groups & $\begin{array}{c}\text { Time of immobility } \\
(\mathbf{s})\end{array}$ & $\begin{array}{c}\text { Values of Immobility } \\
(\%)\end{array}$ \\
\hline Vehicle & $223.70 \pm 1.11$ & - \\
EE 50 & $161.80 \pm 10.91^{\mathrm{a}}$ & $\downarrow 72$ \\
EE 100 & $109.60 \pm 19.92^{\mathrm{a}}$ & $\downarrow 49$ \\
EE 150 & $67.60 \pm 4.01^{\mathrm{a}, \mathrm{b}, \mathrm{c}}$ & $\downarrow 30$ \\
IMI 25 & $115.0 \pm 1.41^{\mathrm{a}}$ & $\downarrow 51$ \\
IMI 50 & $75.00 \pm 1.67^{\mathrm{a}}$ & $\downarrow 66$ \\
PAROX 10 & $82.67 \pm 2.66^{\mathrm{a}}$ & $\downarrow 63$ \\
PAROX 20 & $133.0 \pm 8.02^{\mathrm{a}}$ & $\downarrow 41$ \\
EE 100 + IMI 50 & $106.3 \pm 4.08$ & $\uparrow 42$ \\
EE 150 + IMI 50 & $63.67 \pm 3.44^{\mathrm{d}, \mathrm{e}}$ & $\downarrow 15$ \\
EE 150 + PAROX 20 & $85.3 \pm 3.72^{\dagger}$ & $\downarrow 64$ \\
RESERP 0.25 & $263.7 \pm 5.28^{\mathrm{a}}$ & $\uparrow 18$ \\
RESERP 0.25 + EE 150 & $193.3 \pm 6.53^{\mathrm{a}}$ & $\downarrow 27$ \\
\hline
\end{tabular}

Experiments performed as described in materials and methods. Extract ethanolic (EE) was administered orally. Values are the mean \pm S.E.M. of time of immobility for 7 mice (per group) used in the experiments. ${ }^{a} p<0.01$ (ANOVA followed by Student-Neuman-Keuls $t$-test), significantly different from control. ${ }^{b} p<0.001$ (ANOVA followed by Student-Neuman-Keuls $t$-test), significantly different from EE 50 group. ${ }^{c} p<0.001$ (ANOVA followed by Student-Neuman-Keuls $t$-test), significantly different from EE 100 group. ${ }^{d} p<0.001$ (ANOVA followed by Student-Neuman-Keuls $t$ test), significantly different from EE 150 group. ${ }^{e} p<0.001$ (ANOVA followed by Student-NeumanKeuls $t$-test), significantly different from IMI 50 group. $\mathrm{p}<0.001$ (ANOVA followed by StudentNeuman-Keuls $t$-test), significantly different from PAROX 20 group. $E E=$ ethanolic extract; IMI = imipramine; PAROX = paroxetine; RESERP = reserpine. Drugs were administered $10 \mathrm{~min}$ before $\mathrm{EE}$ and the test performed 30 min later.

Table 4. Effects of EE from $C$. limon in the rota rod test in mice.

\begin{tabular}{lcc}
\hline Groups & Number of falls & Time of permanence (s) \\
\hline Control & $1.71 \pm 0.75$ & $53.71 \pm 1.11$ \\
DZP 0.75 & $2.50 \pm 1.22$ & $52.40 \pm 2.30$ \\
EE 50 & $1.80 \pm 0.34$ & $55.80 \pm 3.11$ \\
EE 100 & $1.72 \pm 0.44$ & $54.00 \pm 1.58$ \\
EE 150 & $1.69 \pm 0.84$ & $44.00 \pm 1.58^{\mathrm{a}, \mathrm{b}, \mathrm{c}, \mathrm{d}}$ \\
\hline
\end{tabular}

Values are the mean \pm SEM of number of falls and time of permanence for 7 mice (per group) used in the experiments. ${ }^{a} p<0.01$ (ANOVA followed by StudentNeuman-Keuls $t$-test), significantly different from control. ${ }^{b} p<0.001$ (ANOVA followed by Student-Neuman-Keuls $t$-test), significantly different from DZP. ${ }^{c} p<0.001$ (ANOVA followed by Student-Neuman-Keuls $t$-test), significantly different from EE 50 group. ${ }^{d} p<0.001$ (ANOVA followed by Student-Neuman-Keuls $t$-test), significantly different from EE 100 group.

system. These effects are indicative of a dopaminergictype action (Mora et al., 2005; Almeida et al., 2012). This test is classical model for screening CNS actions, since it provides information about psychomotor performance, anxiety and locomotor activity. It is well known that benzodiazepines act as anxiolytics (at low doses), anticonvulsants, and also produce sedation and a myorelaxant effect at higher doses (Melo et al., 2006). Anxiety, a symptom accompanying various CNS disorders and a disorder by itself, is characterized in humans by a tense and exhaustive physical alertness (Jackson and Turkington, 2005). Other species display a variety of defensive reactions in response to predators, some understood as correlated states of anxiety (Rodgers et al., 1995).

In order to study the possible anxyolitic effect of EE, the elevated-plus-maze test was used. The results showed that EE was able to significantly decrease the time of permanence as well as the number of entrances in the open arms, indicating a negative response. Our results point out that the sedative effects of EE possibly involve the $\mathrm{GABA}_{\mathrm{A}}$ receptor complex. A sedative action was already shown by essential oil of leaves from $C$. limon (Campêlo et al., 2011a) and Lavandula angustifolia P. 
Table 5. Rectal temperature of mice after administration of EE from Citrus limon.

\begin{tabular}{lc}
\hline Groups & Rectal temperature $\left({ }^{\circ} \mathrm{C}\right)$ \\
\hline Control & $38.00 \pm 0.81$ \\
Diazepam 0.75 & $37.98 \pm 0.83$ \\
EE 50 & $34.80 \pm 0.11^{\mathrm{a}, \mathrm{b}}$ \\
EE100 & $34.70 \pm 0.35^{\mathrm{a}, \mathrm{b}}$ \\
EE150 & $34.50 \pm 0.58^{\mathrm{a}, \mathrm{b}}$ \\
\hline
\end{tabular}

Values are the mean \pm S.E.M. of rectal temperature for 7 mice (per group) used in the experiments. ${ }^{a} p<0.01$ (ANOVA followed by Student-Neuman-Keuls $t$-test), significantly different from control. ${ }^{b} \mathrm{p}<0.001$ (ANOVA followed by Student-Neuman-Keuls $t$-test), significantly different from DZP.

Miller (Lis-Balchin and Hart, 1999), as assessed by the elevated-plus-maze test in rodents. Active constituents of C. limon are primarily monoterpene compounds chemically similar to EE. These monoterpenes exhibit sedative activity that is thought to be due to GABAergic mechanisms. Furthermore, an essential oil from $C$. limon was shown to exert a dose-dependent increase in antioxidant parameters in mice hippocampus (Campêlo et al., 2011b).

The forced swimming test is a behavior test which, in rodents, gives an indication of the clinical efficacy of various types of antidepressant drugs. Nowadays, antidepressants are known to act by several distinct mechanisms at the receptor level, probably also stimulating similar pathways at the sub-cellular level (Yildiz et al., 2002). EE was also able to decrease the immobility time of mice $(50,100$ and $150 \mathrm{mg} / \mathrm{kg})$. At higher doses (100 and $150 \mathrm{mg} / \mathrm{kg}$ ), however, the antidepressant effect was not masked by sedative and hypnotic actions of the drug (data not shown). The EE effect was increased by imipramine, a tricyclic antidepressant (TCA) which blocks the reuptake of both serotonin and norepinephrine. In addition, alterations were seen after EE association with paroxetine, a known selective serotonin reuptake inhibitor. Additionally, EE effects were totally blocked by the reserpine pretreatment, a known inhibitor of the vesicular catecholamine transporter (that facilitates vesicular storage). A similar process occurs at storage sites for 5HT, which can finally result in a depletion of biogenic amines. Furthermore, this finding proposes that the antidepressant effect of EE is probably related, at least in part, to the increase in CNS noradrenergic and serotoninergic activities.

In order to assess whether the EE produces loss of motor coordination of animals, a test was performed on the rota-rod apparatus. Our results suggest that the highest dose of EE produces loss of motor coordination of mice. This result also suggests that increasing the dose leads to an EE amnesic effect, an important characteristic of the benzodiazepine drugs. Thus, lack of coordination and muscle relaxation in the test of the Rota-rod is characteristic of a drug that reduces the CNS activity such as sedatives and hypnotics (Almeida et al., 2012; Silva et al., 2011). Rectal temperature decreased at all doses tested. This result can probably be associated with possible action on the GABAergic system.

\section{Conclusions}

Our results gave support to the idea that EE interacts with the $\mathrm{GABA}_{\mathrm{A}}$ receptor, probably at the receptor subtypes that mediate BDZ effects, to produce sedative and hypnotic activities, and also acts to increase the noradrenergic and serotoninergic activities that is the main factor responsible for its antidepressant activity. Additional studies, however, are needed to fully clarify the mechanism of sedative and antidepressant effects of ethanolic extract of leaves from $C$. limon.

\section{REFERENCES}

Almeida RN, Falcão A, Diniz RST, Quintans-Júnior LJ, Polari RM, Barbosa-Filho JM, Agra MF, Duarte JC, Ferreira CD, Antoniolli AR, Araújo CC (1999). Method for evaluating plants with the central nervous system and some experimental data. Rev Bras Farmacogn. 80:72-76.

Almeida ACC, Costa JP, Carvalho RBF, Sousa DP, Freitas RM (2012). Evaluation of acute toxicity of a natural compound (+)-limonene epoxide and its anxiolytic-like action. Brain Res. 1448:56-62.

Archer J (1973). Tests for emotionality in mices and mice: a review. Anim. Behav. 21:205-235.

Barbosa WLR (2004). Manual para análise fitoquímica e cromatográfica de extratos vegetais. Sci. Rev. UFPA. 4:12-18.

Benavente-Garcia O, Castillo J (2008). Update on uses and properties of citrus flavonoids: new findings in anticancer, cardiovascular, and anti-inflammatory activity. J. Agric. Food Chem. 56:6185-6205.

Bocco A, Cuvelier ME, Richard H, Berset C (1998). Antioxidant activity and phenolic composition of citrus peel and seed extracts. J. Agric. Food Chem. 46:2123-2129.

Buller R, Legrand V (2001). Novel treatments for anxiety and depression: hurdles in bringing them to the market. Drug Discov. Today. 6:1220-1230.

Campêlo LML, Gonçalves FCM, Feitosa CM, Freitas RM (2011a). Evaluation of central nervous system effects of Citrus limon essential oil in mice. Rev. Bras Farmacogn. 21:668-673.

Campêlo LML, Gonçalves FCM, Feitosa CM, Freitas RM (2011b). Antioxidant activity of Citrus limon essential oil in mice hippocampus. Pharm. Biol. 49:709-715.

Choi HS, Song HS, Ukeda H, Sawamura M (2000). Radical-scavenging activities of citrus essential oils and their components: detection using 1,1-diphenyl-2-picrylhydrazyl. J Agric Food Chem. 48:4156-4161.

Conforti F, Statti GA, Tundis R, Loizzo MR, Menichini F (2007). In vitro activities of Citrus medica L. cv. Diamante (Diamante citron) relevant to treatment of diabetes and Alzheimer's disease. Phytother. Res. 21:427-433.

Dunham NW, Miya TS (1957). A note on a simple apparatus for detecting neurological deficit in mices and mice. J. Am. Pharm. Assoc. 46:208-209.

Feitosa CM, Freitas RM, Luz NNN, Bezerra MZB, Trevisan MTS (2011). Acetylcholinesterase Inhibition by somes promising Brazilian medicinal plants. Braz J. Biol. 71:783-789.

Furtado RF, De Lima MG, Andrade Neto M, Bezerra JNS, Silva MG (2005). Atividade larvicida de óleos essenciais contra Aedes aegypti 
L.(Diptera: Culicidae). Neotrop. entomol. 34:843-847.

Hogg S (1966). A review of the validity and variability of the elevated plus-maze as an animal model of anxiety. Pharmacol. Biochem. Behav. 54:21-30.

Jackson MJ, Turkington D (2005). Depression and anxiety in epilepsy. J. Neurol. Neurosurg. Psychiatry. 76:45-47.

Karr LL, Coats JR (1988). Insecticidal properties of a-Limonene. Pesticide Sci. 13:287-290.

Lis-Balchin M, Hart S (1999). Studies on the mode of action of the essential oil of Lavender (Lavandula angustifolia P. Miller). Phytother Res. 13:540-542.

Lister RG (1987). The use of a plus-maze to measure anxiety in the mouse. Psychopharmacology 92:180-185.

Lorenzi H, Matos FJA (2002). Medicinal plants in Brazil: native and exotic. 4th ed. Sao Paulo: Nova Odessa, Instituto Plantarum.

Matos FJA (2009). Introduction to experimental phytochemical. Fortaleza: UFC.

Melo CTV, Monteiro AP, Leite CP, Araújo FL, Lima VT, Barbosa-Filho JM, Fonteles MMF, Vasconcelos SM, Viana GSB, Sousa FC (2006). Anxiolytic-like effects of (O-methyl)-N-2,6-dihydroxybenzoyl-tyramine (Riparin III) from Aniba riparia (NeeS) Mez (Lauraceae) in mice. Biol. Pharm. Bull. 29:451-454.

Misharina TA, Samusenko AL (2008). Antioxidant properties of essential oils from lemon, grapefruit, coriander, clove, and their mixtures. Appl. Biochem. Microbiol. 44:438-442.

Mora S, Díaz-Véliz G, Millán R, Lungenstrass $H$, Quirós S, CotoMorales T, Hellión-Ibarrola MC (2005). Anxiolytic and antidepressantlike effects of the hydroalcoholic extract from Aloysia polystachya in rats. Pharmacol. Biochem. Behav. 82:373-378.
Pereira RB (1996). Evaluation of antioxidant activity of seeds of citrus fruits. [Master's thesis]. Sao Paulo: Faculty of Pharmaceutical Sciences, USP.

Porsolt RD, Bertin A, Jalfre M (1977a). Behavioral despair in mice: a primary screening test for antidepressants. Arch Int Pharmacodyn Ther. 229:327-336.

Porsolt RD, Le Pichon M, Jalfre M (1977b). Depression: a new animal model sensitive to antidepressant treatments. Nature. 266:730-732.

Porsolt RD, Anton G, Blavet N, Jalfre M (1978). Behavioural despair in mices: a new model sensitive to antidepressant treatments. Eur. J. Pharmacol. 47:79-391.

Rodgers RJ, Cole JC, Aboualfa K, Stephenson LH (1995). Ethopharmacological analysis of the effects of putative 'anxiogenic' agents in the mouse elevated plus-maze. Pharmacol. Biochem. Behav. 52:805-813.

Silva FO, Silva MGV, Feng D, Freitas RM (2011). Evaluation of central nervous system effects of iso-6-cassine isolated from Senna spectabilis var. excelsa (Schrad) in mice. Fitoterapia 82:255-259.

WHO (World Health Organization) (1999). Director-General unveils new global strategies for mental health. Press Release WHO/99-67.

Yildiz A, Gonul AS, Tamarn L (2002). Mechanism of actions of antidepressants: beyond the receptors. Bull. Clin. Psychopharmacol. 12:194-200. 